\title{
LIFE CYCLE ASSESSMENT OF DOMESTIC WASTEWATER TREATMENT IN MEDAN CITY, INDONESIA
}

\author{
Ira Rumiris Hutagalung ${ }^{*}, 1$, Toru Matsumoto² \\ ${ }^{1)}$ Graduate School of Environmental Engineering, the University of Kitakyushu, Japan \\ ${ }^{2)}$ Faculty of Environmental Engineering, the University of Kitakyushu, Japan
}

\begin{abstract}
Medan City already has been having Waste Water Treatment Plant (WWTP) under PDAM Tirtanadi (North Sumatera Government) supervision, namely IPAL Cemara. IPAL Cemara is off-site sewerage system to treat domestic wastewater, includes black and grey water. IPAL Cemara has maximum capacity $60,000 \mathrm{~m}^{3} /$ day, but recently, the number of treated households by IPAL Cemara is 18,396 households and the used capacity is less than $10,000 \mathrm{~m}^{3} /$ day. This research analyses on operational phase of IPAL Cemara on environmental impacts, starts at wastewater influent from households and ending at release of wastewater effluent and disposal of dry sludge. The phase of reuse or recycle of effluent wastewater and dry sludge, and waste management are not included. Functional unit in this research is treatment of 7,171 $\mathrm{m}^{3}$ wastewater per day for a year. The system boundary starts at wastewater influent and ends at release of wastewater effluent. The characterization factors are tracked based on CML Baseline 2001 and all of data processed by Microsoft Excel. For the result, got that Aerated Pond has removal efficiency of BOD and COD more than $70 \%$, but on the other hand, it is the largest contributor to Climate Change impact because of diesel consumption (16.97\%), the amount of $\mathrm{CO}_{2}(4,95 \%)$, and $\mathrm{N}_{2} \mathrm{O}$ (4.26\%) from biogenic emission, and electricity use (3.04\%). The $65 \%$ reducing of TSS is occurred in UASB Reactor but UASB Reactor also as contributor for Climate Change impact (16.63\%) and Photo-Oxidant Formation impact (29.34\%) due to the highest production of $\mathrm{CH}_{4}$. Facultative Pond contributes $49 \%$ of Climate Change impact and $31 \%$ of Photo-Oxidant Formation impact because of the highest production of $\mathrm{CH}_{4}$. Based on normalized by impact category, Freshwater Ecotoxicity and Eutrophication is the largest environmental impact in a whole system of IPAL Cemara. Freshwater Ecotoxicity caused by $72 \% \mathrm{CS}_{2}$ at Release of Wastewater and Eutrophication caused by $41.25 \%$ of $\mathrm{NH}_{3}$ and $39.60 \%$ of $\mathrm{N}$. It is Align with the result of normalized by Life Cycle Stage, shows that the Release of Wastewater Effluent is the largest contributor to environment in a whole system of IPAL Cemara.
\end{abstract}

Keywords: Life Cycle Assessment, Domestic Wastewater Treatment

\section{Introduction}

Medan City where is the capital city of North Sumatera province is the $3^{\text {rd }}$ biggest city in

\footnotetext{
${ }^{*}$ Corresponding Author:

E-mail: irarumirishutagalung@gmail.com
}

Received: 3 April 2020

Revised : 13 July 2020

Accepted: 12 September 2020
Indonesia with the large area is $265.10 \mathrm{~km}^{2}$, consists of 2,210,624 inhabitants. The average density of Medan City is 8,338 person $/ \mathrm{km}^{2}$ and the average household size is 4.35 people/ household. The population of Medan City always increases year by year and for along 15 recently years, the increasing reaches $16 \%$.

The increasing of population will increase household consumption of water and directly 
impacted to increase domestic wastewater production (Prinajati, 2020). As we have known that around $80 \%$ water consumption becomes wastewater (www.iges.or.jp, accessed March 2017). Domestic wastewater disposal without adequate treatment causes water sources contamination for drinking water, ground water, and river water (Yustiani et.al, 2018). Rapidly increasing of population leads some environmental issues in Medan City and the $2^{\text {nd }}$ biggest issue is decreasing rivers quality (Book of Environmental Status of Medan City, 2015).

Since 1995, Medan City already has been having Waste Water Treatment Plant (WWTP) under PDAM Tirtanadi (North Sumatera Government) supervision, namely IPAL Cemara. IPAL Cemara is off-site sewerage system to treat domestic wastewater, includes black and grey water. IPAL Cemara covers some areas of Medan City and Deli Serdang Regency with total coverage areas are $520 \mathrm{Ha}$ of Medan City and 150 Ha of Deli Serdang Regency. However, the coverage area is low, only $3.63 \%$ of domestic wastewater is treated by IPAL Cemara. Approximately, $96.37 \%$ of households in Medan City rely on on-site sewerage systems; those are septic tank or latrine pit for treating black water and open drainage for grey water.

Life Cycle Assessment (LCA) is technique for assessing the potential environmental aspects and potential aspects associated with a product or service, by: compiling an inventory of relevant inputs and outputs, evaluating the potential environmental impacts associated with those inputs and outputs, and interpreting results of the inventory and impact phases in relation to the objectives of the study (ISO 14040.2 Draft : Life Cycle Assessment-Principles and Guideliness (http://www.gdrc.org, accessed March 2017).

Recently, many LCA researches relate to domestic wastewater treatment, such as Application of LCA for an Evaluation of
Wastewater Treatment and Reuse Project - Case Study of Xi'an, China (Zang et. Al, 2010), LCA of Wastewater Treatment Plants in Ireland (Mcnamara et.al, 2016), Comprehensive Life Cycle Inventories of Alternative Wastewater Treatment Systems (Foley et. Al, 2010), and LCA of a Municipal Wastewater Treatment Plant: A Case Study in Suzhou, China (Li et. al, 2013).

The objectives of this research are to find the operational impact of IPAL Cemara on environment by a whole system and each life cycle stage and to establish LCA framework of IPAL Cemara that could use as baseline to conduct continuous improvement and further deeply analysis.

\section{Research Methodology}

This research analyses on operational phase of IPAL Cemara on environmental impacts, starts at wastewater influent from households and ending at release of wastewater effluent and disposal of dry sludge. The phase of reuse or recycle of effluent wastewater and dry sludge, and waste management are not included.

\section{a. Goal and Scope}

This research aim at analyses on operational stage of IPAL Cemara on environmental impacts for establishing LCA framework that could be used to further research such as continuous improvement of IPAL Cemara. The research's scope includes wastewater influent, treatment and maintenance, treated water release, and disposed dry sludge. Functional unit in this research is treatment of $7,171 \mathrm{~m}^{3}$ wastewater per day for a year. The system boundary starts at wastewater influent and ends at release of wastewater effluent. Electricity for operating machine and pump, diesel as generator fuel, lubricant consumption for operating and maintaining machine and pump are included within the system boundaries. Biogenic emissions, treated wastewater effluent, and 
disposed dry sludge are also included within the system boundaries. By-product production such as large solids, rags, debris, sand, gravel, cinder from Screening and Grit Chamber, also sludge from Aerated Pond and Facultative Pond are calculated but the environmental impacts of them are not take account. Based on interview with IPAL Cemara staff, the estimation of lubricant spill is $3 \%$ of lubricant residue, $97 \%$ is collected well and given to third party.

b. Life Cycle Inventory (LCI)

The LCI of this research is CML Baseline 2001 from Leiden University. Accordance with CML
2001 guidance, there are some required data of IPAL Cemara operational, such as electricity use of each pump and machine, diesel consumption as generator fuel of each and machine, the amount of $\mathrm{CO}_{2}, \mathrm{CH}_{4}$, and $\mathrm{N}_{2} \mathrm{O}$ as air emission from electricity use, diesel and lubricant consumption, biogenic emissions, the constituents of treated wastewater effluent as water emission and disposed dry sludge as soil emission, and the number production of byproducts. All of data in Life Cycle Inventory is collected based on the functional unit, which is treatment of $7,171 \mathrm{~m}^{3}$ wastewater per day for a year.

Table 1. Data Sources

\begin{tabular}{|c|c|c|c|c|}
\hline No & Life Cycle Stage & Unit Process/Process Emission & Required Data & Sources \\
\hline 1 & Influent Box & Input and Output of Wastewater & Debit & Measured by Environmental Agency of North Sumatera Province \\
\hline \multirow{4}{*}{2} & \multirow{4}{*}{ Screw Pump } & Input and Output of Wastewater & Debit & Measured by Environmental Agency of North Sumatera Province \\
\hline & & Electricity & Quantity Used & Direct from IPAL Cemara \\
\hline & & Diesel and Lubricant Consumption & Quantity Used & Direct from IPAL Cemara \\
\hline & & $\begin{array}{l}\mathrm{CO}_{2}, \mathrm{CH}_{4}, \mathrm{~N}_{2} \mathrm{O} \text { (from electricity use, diesel } \\
\text { consumption) }\end{array}$ & Quantity Generated & Estimation \\
\hline \multirow{5}{*}{3} & \multirow{5}{*}{ Screening } & Input and Output of Wastewater & Debit & Measured by Environmental Agency of North Sumatera Province \\
\hline & & Large Solids, Rags, Debris & Quantity Generated & Estimation \\
\hline & & Electricity & Quantity Used & Direct from IPAL Cemara \\
\hline & & Diesel and Lubricant Consumption & Quantity Used & Direct from IPAL Cemara \\
\hline & & $\begin{array}{l}\mathrm{CO}_{2}, \mathrm{CH}_{4}, \mathrm{~N}_{2} \mathrm{O} \text { (from electricity use, diesel } \\
\text { consumption) }\end{array}$ & Quantity Generated & Estimation \\
\hline \multirow{5}{*}{4} & \multirow{5}{*}{ Grit Chamber } & Input and Output of Wastewater & Debit & Measured by Environmental Agency of North Sumatera Province \\
\hline & & Sand, Gravel, Cinder, and Other Heavy Solids & Quantity Generated & Estimation \\
\hline & & Electricity & Quantity Used & Direct from IPAL Cemara \\
\hline & & Diesel and Lubricant Consumption & Quantity Used & Direct from IPAL Cemara \\
\hline & & $\begin{array}{l}\mathrm{CO}_{2}, \mathrm{CH}_{4}, \mathrm{~N}_{2} \mathrm{O} \text { (from electricity use, diesel } \\
\text { consumption) }\end{array}$ & Quantity Generated & Estimation \\
\hline 5 & Splitter Box & Input and Output of Wastewater & Debit & Measured by Environmental Agency of North Sumatera Province \\
\hline \multirow{3}{*}{6} & \multirow{3}{*}{ UASB Reactor } & Input and Output of Wastewater & Debit & Measured by Environmental Agency of North Sumatera Province \\
\hline & & Sludge & Quantity Generated & Estimation \\
\hline & & $\mathrm{CO}_{2}, \mathrm{CH}_{4}, \mathrm{~N}_{2} \mathrm{O}$ (from biogenic emissions) & Quantity Generated & Estimation \\
\hline 7 & Skimming Tank & Input and Output of Wastewater & Debit & Measured by Environmental Agency of North Sumatera Province \\
\hline \multirow{6}{*}{8} & \multirow{6}{*}{ Aerated Pond } & Input and Output of Wastewater & Debit & Measured by Environmental Agency of North Sumatera Province \\
\hline & & Sludge & Quantity Generated & Estimation \\
\hline & & Electricity & Quantity Used & Direct from IPAL Cemara \\
\hline & & Diesel and Lubricant Consumption & Quantity Used & Direct from IPAL Cemara \\
\hline & & Oxygen & Quantity Used & Direct from IPAL Cemara \\
\hline & & $\begin{array}{l}\mathrm{CO}_{2}, \mathrm{CH}_{4}, \mathrm{~N}_{2} \mathrm{O} \text { (from electricity use, } \\
\text { biogenic emissions, diesel consumption) }\end{array}$ & Quantity Generated & Estimation \\
\hline \multirow{3}{*}{9} & \multirow{3}{*}{ Facultative Pond } & Input and Output of Wastewater & Debit & Measured by Environmental Agency of North Sumatera Province \\
\hline & & Sludge & Quantity Generated & Estimation \\
\hline & & $\mathrm{CO}_{2}, \mathrm{CH}_{4}, \mathrm{~N}_{2} \mathrm{O}$ (from biogenic emissions) & Quantity Generated & Estimation \\
\hline \multirow{4}{*}{10} & \multirow{4}{*}{ Sludge Drying Beds } & Electricity & Quantity Used & Direct from IPAL Cemara \\
\hline & & Diesel and Lubricant Consumption & Quantity Used & Direct from IPAL Cemara \\
\hline & & Dry Sludge & Quantity Generated & Estimation \\
\hline & & $\begin{array}{l}\mathrm{CO}_{2}, \mathrm{CH}_{4}, \mathrm{~N}_{2} \mathrm{O} \text { (from electricity use, diesel } \\
\text { consumption) }\end{array}$ & Quantity Generated & Estimation \\
\hline 11 & Disposal of Dry Sludge & Constituents of disposed dry sludge & Quantity Generated & Measured by Environmental Agency of North Sumatera Province \\
\hline \multirow{2}{*}{12} & \multirow{2}{*}{$\begin{array}{l}\text { Release of Wastewater } \\
\text { Effluent }\end{array}$} & Input and Output of Wastewater & Debit & Measured by Environmental Agency of North Sumatera Province \\
\hline & & Constituents of treated wastewater effluent & Quantity Generated & Measured by Environmental Agency of North Sumatera Province \\
\hline
\end{tabular}


- The electricity-specific emission factors for grid electricity of Indonesia are : $6.8 \mathrm{E}-01$ $\mathrm{kgCO}_{2} / \mathrm{kWh}$ for $\mathrm{CO}_{2}, 1.45 \mathrm{E}-05 \mathrm{kgCH}_{4} / \mathrm{kWh}$ for $\mathrm{CH}_{4}$, and 7.8E-06 $\mathrm{kgN}_{2} \mathrm{O} / \mathrm{kWh}$ for $\mathrm{N}_{2} \mathrm{O}$ (Brander, 2011).

- The emission factor of sludge is 0.4 tonnes $\mathrm{CO}_{2}$-eq. (Australian National Greenhouse Accounts, 2015).

- Formula for estimating fuel combustion of diesel (Australian National Greenhouse Accounts, 2015) :

$$
E i j=\frac{\text { Qi } x \text { ECi } x \text { EFijoxec }}{1000}
$$

Whre Eij is the emission of gas type (j), (carbon dioxide, methane or nitrous oxide, from fuel type (i) $\left(\mathrm{CO}_{2}\right.$-e tonnes), Qi is the quantity of diesel (Kilolitres) combusted for stationary energy purposes, ECi is the energy content factor of diesel (Gigajoule per Kilolitre) for stationary energy purposes, ECi Diesel equal to $38.6 \mathrm{Gj} / \mathrm{kL}$, EFijoxec is the emission factor for each gas type (j) (which includes the effect of an oxidation factor) for diesel (Kilograms CO2-eq. per gigajoule), $\mathrm{EF}$ $\mathrm{CO}_{2}=69.9, \mathrm{EF} \mathrm{CH}_{4}=0.1, \mathrm{EF} \mathrm{N} \mathrm{N}_{2} \mathrm{O}=0.2$.

- Aerobic wastewater treatment systems produce primarily $\mathrm{CO}_{2}$, whereas anaerobic systems produce a mixture of $\mathrm{CH}_{4}$ and $\mathrm{CO}_{2}$. Following equations provide a general means of estimating the $\mathrm{CO}_{2}$ and $\mathrm{CH}_{4}$ emissions directly from any type of wastewater treatment process assuming all organic carbon removed from the wastewater is converted either $\mathrm{CO}_{2}, \mathrm{CH}_{4}$, or new biomass (RTI International, 2010).

$$
\begin{aligned}
& C O_{2}=10^{-6} \times Q_{w w} \times O D \times E f f_{O D} \times C F_{C O 2} \times \\
& {\left[\left(1-M C F_{w w} \times B G_{C H 4}\right)(1-\lambda)\right]} \\
& C H_{4}=10^{-6} \times Q_{w w} \times O D \times E f f_{O D} \times C F_{C H 4} \times \\
& {\left[\left(M C F_{w w} \times B G_{C H 4}\right)(1-\lambda)\right]}
\end{aligned}
$$

Where $\mathrm{CO}_{2}$ is $\mathrm{CO}_{2}$ emission rate $\left(\mathrm{MgCO}_{2} / \mathrm{hr}\right)$, $\mathrm{CH}_{4}$ is $\mathrm{CH}_{4}$ emission rate $\left(\mathrm{MgCH}_{4} / \mathrm{hr}\right), 10^{-6}$ is Units conversion factor $(\mathrm{Mg} / \mathrm{g}), \mathrm{Q}_{\mathrm{ww}}$ is wastewater influent flow rate $\left(\mathrm{m}^{3} / \mathrm{hr}\right)$, OD is Oxygen demand of influent wastewater to the biological treatment unit determined as either $\mathrm{BOD}_{5}$ or $\mathrm{COD}(\mathrm{mg} / \mathrm{L}), \mathrm{Eff}_{\mathrm{OD}}$ is Oxygen demand removal efficiency of the biological treatment unit, $\mathrm{CF}_{\mathrm{CO} 2}$ is Conversion factor for maximum $\mathrm{CO}_{2}$ generation per unit of oxygen demand equal to $44 / 32$ or $1.375 \mathrm{gCO}_{2} / \mathrm{g}$ oxygen demand, $\mathrm{CF}_{\mathrm{CH} 4}$ is Conversion factor for maximum $\mathrm{CH}_{4}$ generation per unit of oxygen demand equal to $16 / 32$ or $0.5 \mathrm{gCH}_{4} / \mathrm{g}$ oxygen demand, $\mathrm{MCF}_{\mathrm{Ww}}$ is Methane correction factor for wastewater treatment unit, indicating the fraction of the influent oxygen demand that is converted in anaerobic condition in the wastewater treatment unit, $\mathrm{CF}$ is aerated treatment process equal to $0, \mathrm{MCF}$ is anaerobic treatment process equal to $0.8, \mathrm{MCF}$ facultative lagoon, deep ( $\geq 2 \mathrm{~m}$ deep) equal to $0.2, \mathrm{BG}_{\mathrm{CH} 4}$ is Fraction of carbon as $\mathrm{CH}_{4}$ in generated biogas (default is 0.65), $\lambda$ is Biomass yield (g C converted to biomass/g C consumed in the wastewater treatment process), $\lambda$ aerated treatment process equal to $0.65, \lambda$ anaerobic treatment process equal to $0.1, \lambda$ facultative lagoon, deep ( $\geq 2 \mathrm{~m}$ deep) equal to 0

- The wastewater treatment process (aerobic, anaerobic, or combination of aerobic and anaerobic) will affect the magnitude of the $\mathrm{N}_{2} \mathrm{O}$ emissions. This equation using to estimate $\mathrm{N}_{2} \mathrm{O}$ emissions for both aerobic and anaerobic process using an average value for percent of influent TKN emitted as $\mathrm{N}_{2} \mathrm{O}$ (RTI International, 2010).

$\mathrm{N}_{2} \mathrm{O}=Q i \times T K N \times E F_{N 2 \mathrm{O}} \times \frac{44}{28} \times 10^{-6}$

Where $\mathrm{N}_{2} \mathrm{O} \mathrm{N} \mathrm{N}_{2} \mathrm{O}$ is emissions generated from WWTP process, Qi is Wastewater influent flow rate $\left(\mathrm{m}^{3} / \mathrm{hr}\right)$, TKNi is Amount of TKN in the influent $(\mathrm{mg} / \mathrm{L}), \mathrm{EF}_{\mathrm{N} 2 \mathrm{O}}$ is $\mathrm{N}_{2} \mathrm{O}$ emission factor ( $\mathrm{g} \mathrm{N}$ emitted as $\mathrm{N}_{2} \mathrm{O}$ per $\mathrm{g}$ TKN in influent, $0.0050 \mathrm{~g} \mathrm{~N}$ emitted as $\mathrm{N}_{2} \mathrm{O} / \mathrm{gTKN}$, $44 / 28$ is Molecular weight conversion, $\mathrm{gN}_{2} \mathrm{O}$ 
per $\mathrm{g} \mathrm{N}$ emitted as $\mathrm{N}_{2} \mathrm{O}, 10^{-6}$ is Units conversion factor $(\mathrm{Mg} / \mathrm{g})$.

- The following equation to estimates sludge production of UASB Reactor, Aerated Pond and Facultative Pond (Andreoli et al, 2007) :

$P=(Q \times S o) \times Y$

Where $\mathrm{P}$ is Sludge production $(\mathrm{kgSS} / \mathrm{d}), \mathrm{Q}$ is Influent flow $\left(\mathrm{m}^{3} / \mathrm{d}\right)$, So is Concentration of influent COD (mg/L), Y is Solids production coefficient (kgSS/kgCODapplied) Y UASB Reactor equal to $0.18 \mathrm{kgSS} / \mathrm{kgCODapplied} \mathrm{Y}$ Facultative Pond equal to 0.22 $\mathrm{kgSS} / \mathrm{kgCODapplied} \mathrm{Y}$ Aerated Pond is equal to $0.3 \mathrm{kgSS} / \mathrm{kgCODapplied}$.

- And this is the equation for estimating dry sludge production of Sludge Drying Beds :

$X=P \times$ Solids capture

Where $X$ is dry sludge production $(\mathrm{kgSS} / \mathrm{d})$, $\mathrm{P}$ is Sludge production $(\mathrm{kgSS} / \mathrm{d})$, Solids capture is equal to $90-98 \%$,

Sludge Flow $=$ SS load $/$ Dry Solid/100 $) \times$

Sludge Density

Where Sludge Flow is in $\mathrm{m}^{3} / \mathrm{d}$, SS load is in $\mathrm{kgSS} / \mathrm{d}$, Dry Solid Sludge is in \%, and Sludge Density is in $\mathrm{kg} / \mathrm{m}^{3}$.

- Element Concentration of Lubricant consists of $0.0275895 \%$ of $\mathrm{As}^{5+}, 0.0318925 \%$ of $\mathrm{Cd}^{2+}, \quad 0.0000004 \%$ of $\mathrm{Co}, 0.0833855 \%$ of Mo, $0.0086207 \%$ of $\mathrm{Ni}^{2+}, 0.0002657 \%$ of $\mathrm{Pb}^{2+}$, and $5.2111300 \%$ of $\mathrm{Zn}^{2+}$.

- Quantities of residual from Screening vary from 4 to $40 \mathrm{~mL} / \mathrm{m}^{3}$ of wastewater and for Grit Chamber is 4 to $200 \mathrm{~mL} / \mathrm{m}^{3}$ of wastewater (Turovskiy, I.S., 2006).

c. Life Cycle Impact Assessment

There are 7 impact categories are used for analyzing environmental impact of IPAL Cemara. The characterization factors are tracked based on CML Baseline 2001 and all of data processed by Microsoft Excel.
Table 2. Impact Categories and Characterisation Factors

\begin{tabular}{|c|c|c|}
\hline No & Impact Category & Characterisation Factor \\
\hline 1 & Abiotic Depletion & $\mathrm{ADP}_{\text {Fassil }}$ in kgantimony-eq. \\
\hline 2 & Climate Change & $\mathrm{GWP}_{100 \text { in }} \mathrm{kgCO}_{2}$-eq. \\
\hline 3 & Human Toxicity & $\mathrm{HTP}_{\text {inf. }}$ in kg 1,4-dichlorobenzene-eq. \\
\hline 4 & Freshwater Ecotoxicity & FAETP $_{\text {inf }}$ in kg1,4-dichlorobenzene-eq. \\
\hline 5 & Terrestrial Ecotoxicity & TAETP $_{\text {inf. }}$ in kg 1,4-dichlorobenzene-eq. \\
\hline 6 & Eutrophication & $\mathrm{EP}$ in $\mathrm{kgPO}_{4}$-eq. \\
\hline 7 & Photo-Oxidant Formation & POCP in kgethylene-eq. \\
\hline
\end{tabular}

Abiotic Depletion (ADP Fossil) represents the number of diesel and lubricant consumption, Climate Change is measured by the amount of $\mathrm{CO} 2, \mathrm{CH} 4$, and $\mathrm{N} 2 \mathrm{O}$ from electricity use, diesel consumption, and biogenic emissions (UASB Reactor, Aerated Pond, Facultative Pond, and Disposal of Dry Sludge). Human Toxicity, Freshwater Ecotoxicity, and Terrestrial Ecotoxicity represent environmental pollution by the constituents of lubricant consumption, wastewater effluent, and disposal dry sludge. Eutrophication measured based on the amount of $\mathrm{N}_{2} \mathrm{O}$ from electricity use and biogenic emissions, and constituents of lubricant consumption, wastewater effluent and disposal dry sludge. Photo-Oxidant Formation represents the amount of $\mathrm{CH}_{4}$ from electricity use and biogenic emissions.

\section{d. Normalization}

Normalization is an optional step in LCA that aids in understanding the significance of the impact assessment results. Normalization is conducted by dividing the impact category results by a normalized value (EPA, 2014). Indonesia does not has normalization factor therefore this research use normalization factors of World 2010 (Sleeswijk, 2008).

Table 3. Normalization Factor

\begin{tabular}{cll}
\hline No & \multicolumn{1}{c}{ Impact Category } & \multicolumn{1}{c}{ Normalisation Factor } \\
\hline \hline 1 & Abiotic Depletion Fossil & $7.8 \mathrm{E}+12 \mathrm{kgSb}-\mathrm{eq}$. \\
2 & Climate Change & $4.2 \mathrm{E}+13 \mathrm{kgCO}_{2}$-eq. \\
3 & Human Toxicity & $8.9 \mathrm{E}+12 \mathrm{kgl}$,4-dichlorobenzene-eq. \\
4 & Freshwater Ecotoxicity & $3.1 \mathrm{E}+10 \mathrm{kgl}$,4-dichlorobenzene-eq. \\
5 & Terrestrial Ecotoxicity & $5.1 \mathrm{E}+10 \mathrm{kgl}$,4-dichlorobenzene-eq. \\
6 & Eutrophication & $3.8 \mathrm{E}+09 \mathrm{kgP}-$ eq. \\
7 & Photo-Oxidant Formation & $2.8 \mathrm{E}+10 \mathrm{kgNMVOC}$-eq. \\
\hline
\end{tabular}


e. Interpretation

Interpretation is based on the result of characterized impact category for analyzing per impact category and also based on normalized impact category for analyzing based on normalized by impact category and normalized by life cycle stage.

\section{Results and Discussion}

Quality of Wastewater Effluent
The quality of wastewater effluent is below government standard quality which each parameter is reduced gradually process by process. All parameters have reduction efficiency $>90 \%$ except fats, oil, and grease however its effluent value already below government standard quality.

Table 4. Comparison the Quality of Wastewater Effluent and Government Standart Quality

\begin{tabular}{clccccc}
\hline No & \multicolumn{1}{c}{ Parameter } & Unit & Standart Quality & Wastewater Influent & Wastewater Effluent & Efficiency (\%) \\
\hline \hline 1 & Biological Oxygen Demand (BOD) & $\mathrm{mg} / \mathrm{L}$ & 30 & 326 & 22.4 & $93 \%$ \\
2 & Chemical oxigen demand (COD) & $\mathrm{mg} / \mathrm{L}$ & 100 & 639 & 44 & $93 \%$ \\
3 & Total Suspended Solids (TSS) & $\mathrm{mg} / \mathrm{L}$ & 30 & 561 & 5 & $99 \%$ \\
4 & Fats, Oil and Grease & $\mathrm{mg} / \mathrm{L}$ & 5 & 1.40 & 0.97 & $31 \%$ \\
5 & $\mathrm{pH}$ & - & $6-9$ & 6.94 & 6.92 & - \\
6 & Total Coliform & $\mathrm{CFU} / 100 \mathrm{~mL}$ & 3000 & 651,344 & 288 & $100 \%$ \\
\hline
\end{tabular}

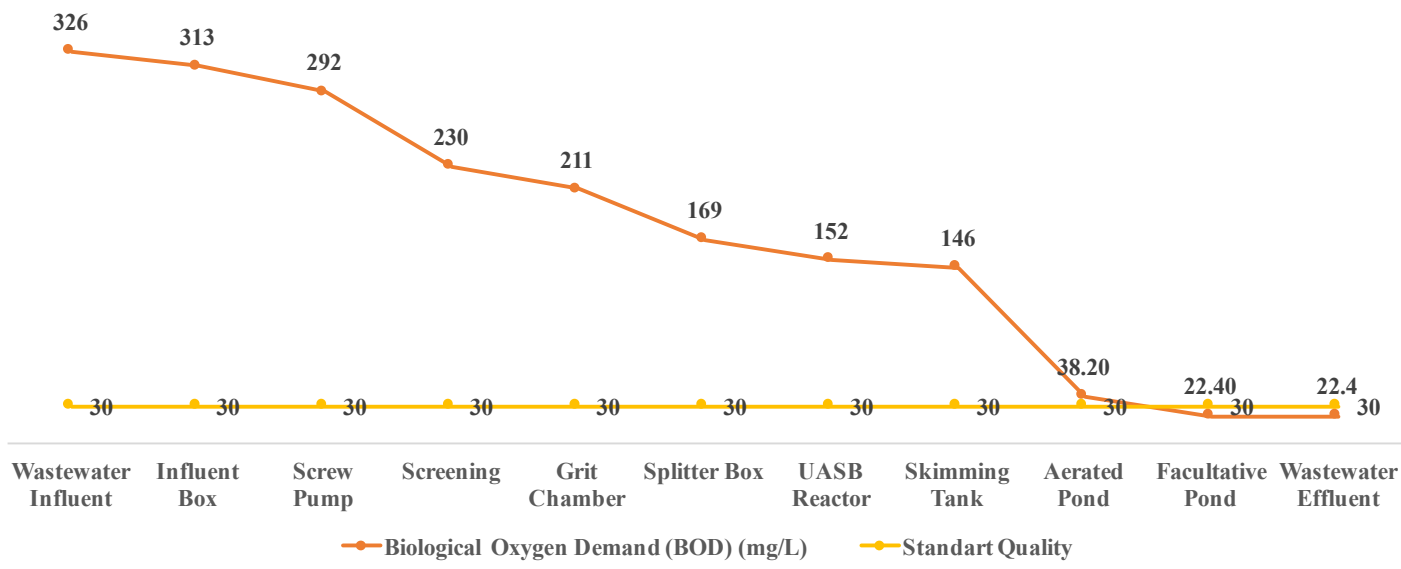

Fig. 1. Actual BOD Comparison to Government Standart Quality

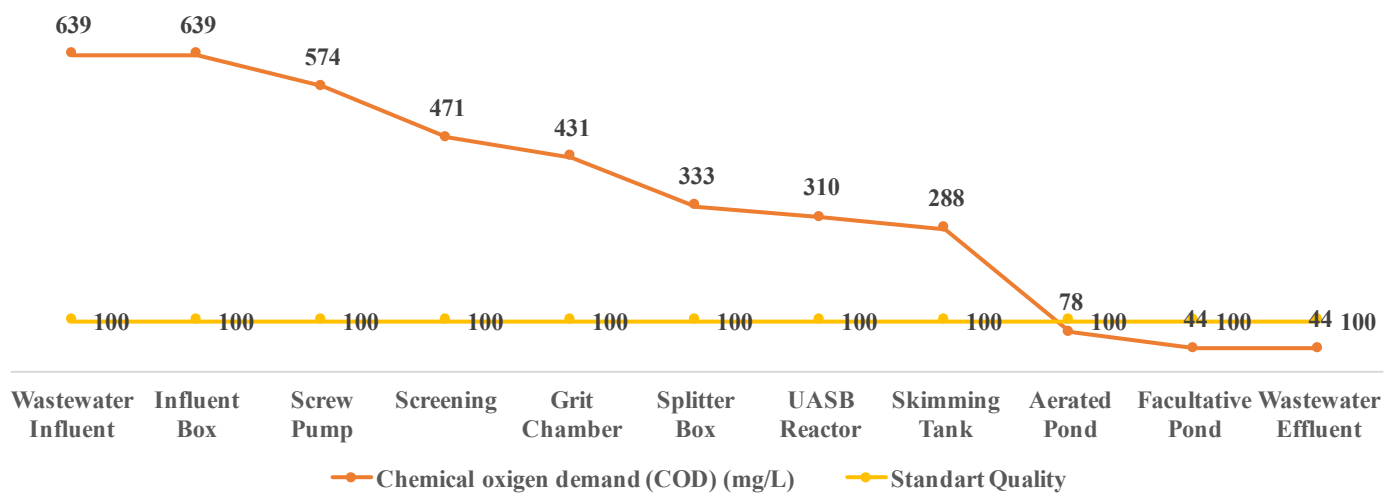


Fig. 2. Actual COD Comparison to Government Standart Quality

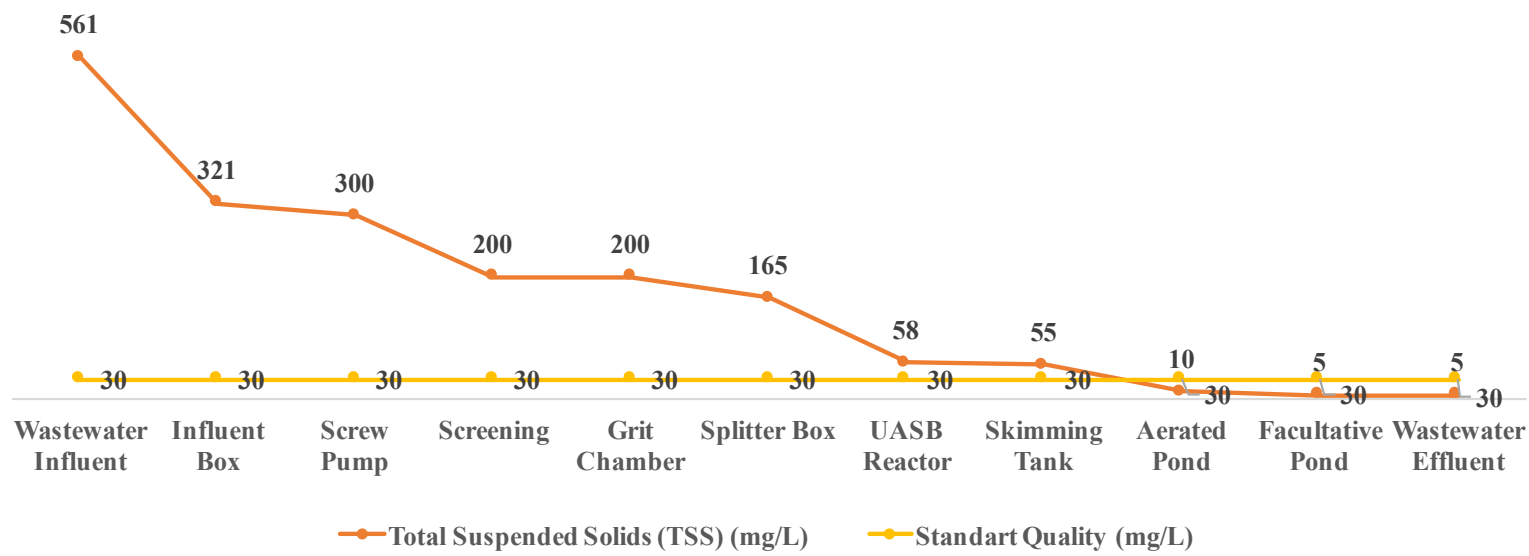

Fig. 3. Actual TSS Comparison to Government Standart Quality

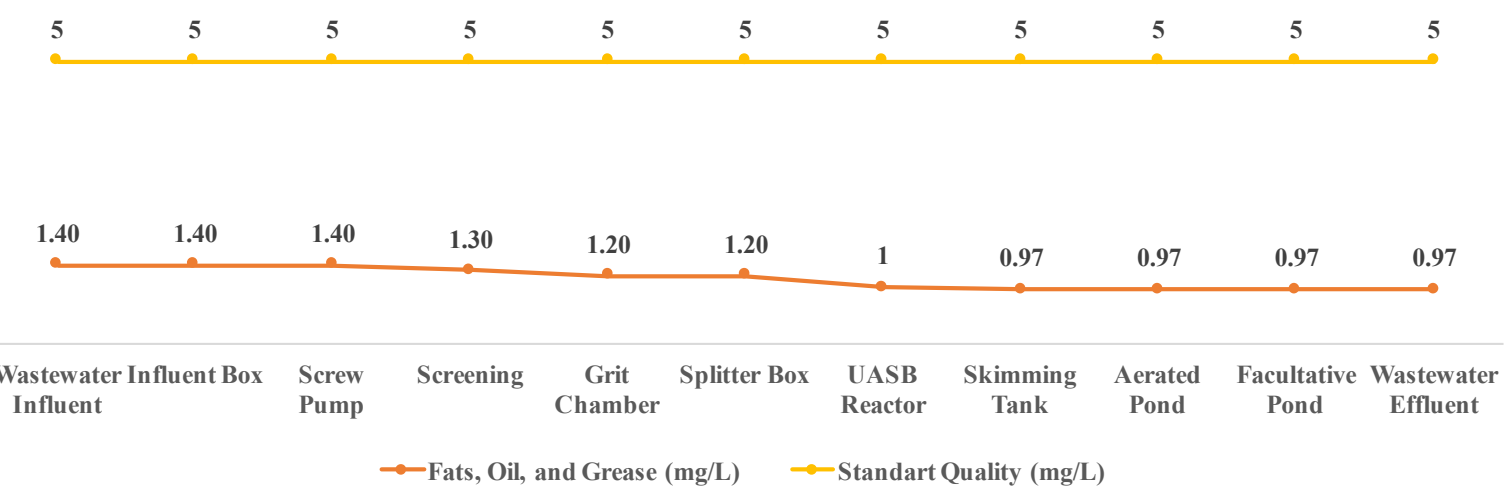

Fig. 4. Actual Fats, Oil, and Grease Comparison to Government Standart Quality

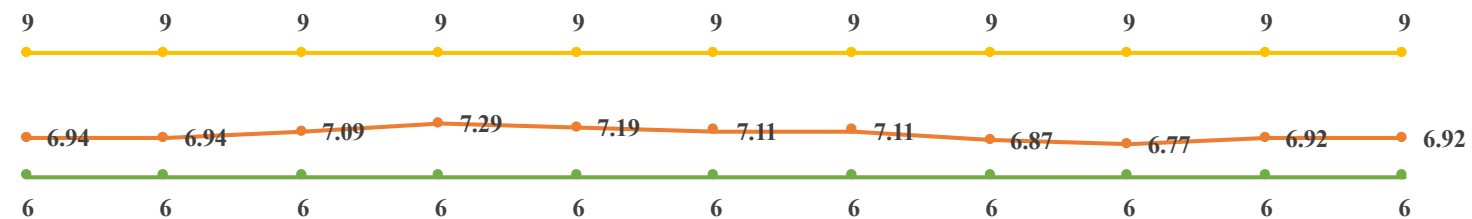

\begin{tabular}{|c|c|c|c|c|c|c|c|c|}
\hline $\begin{array}{l}\text { Wastewater Influent Box Screw Pump } \\
\text { Influent }\end{array}$ & Screening & $\begin{array}{c}\text { Grit } \\
\text { Chamber }\end{array}$ & Splitter Box & $\begin{array}{l}\text { UASB } \\
\text { Reactor }\end{array}$ & $\underset{\text { Tank }}{\text { Skimming }}$ & $\begin{array}{l}\text { Aerated } \\
\text { Pond }\end{array}$ & $\begin{array}{l}\text { Facultative } \\
\text { Pond }\end{array}$ & $\begin{array}{l}\text { Wastewater } \\
\text { Effluent }\end{array}$ \\
\hline
\end{tabular}

Fig. 5. Actual pH Comparison to Government Standart Quality 


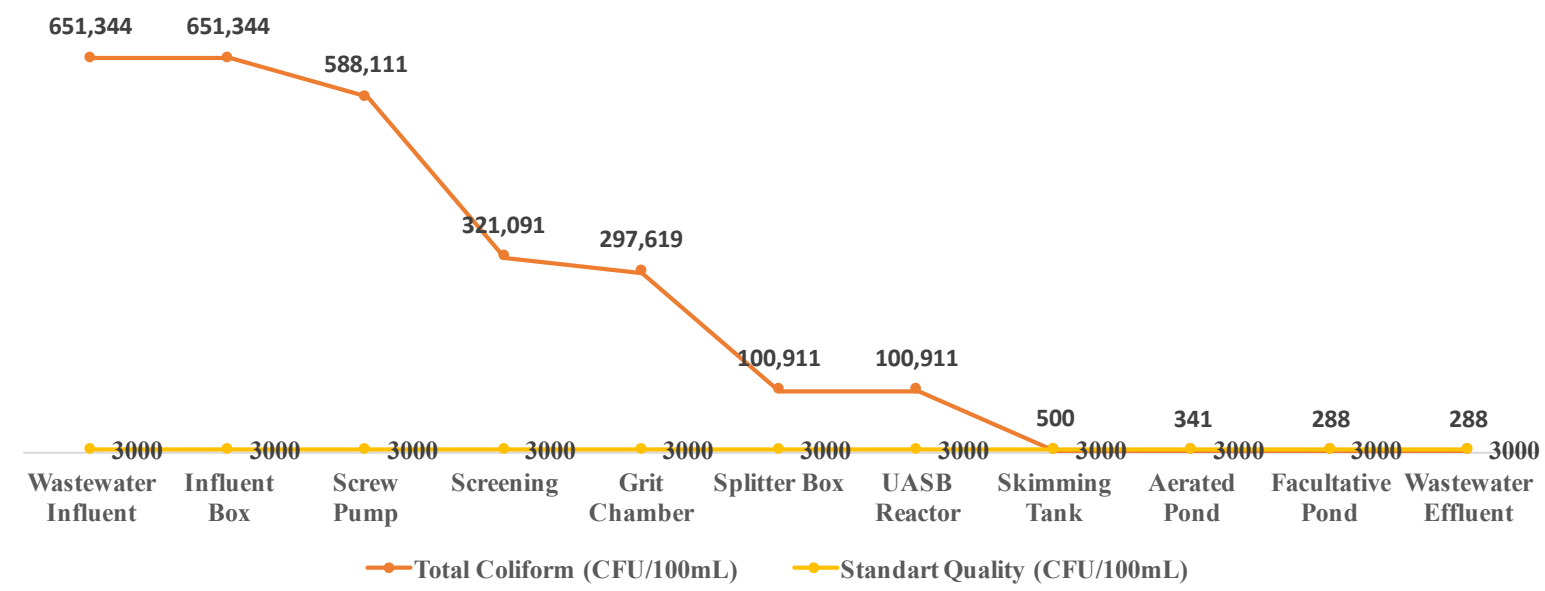

Fig. 6. Actual Total Coliform Comparison to Government Standart Quality

Actual BOD and COD are highly reduced in Aerated Pond up to $74 \%$ and $73 \%$ respectively, TSS is reduced around 65\% in UASB Reactor, Total Coliform is reduced extremely $99 \%$ in Skimming Tank, meanwhile Fats, Oil, and Grease and $\mathrm{pH}$ are stable reduced in each process even the beginning value (fats, oil, and grease of wastewater influent) is below government standard quality.

\section{Life Cycle Inventory ( $L C I)$}

In this research, the LCI is conducted base on the functional unit, which is the treatment of
$7,171 \mathrm{~m}^{3}$ wastewater per day for a year. Flow rate of effluent wastewater is higher $49 \%$ than influent wastewater.

Table 5. LCI of Wastewater Debit

\begin{tabular}{clcc}
\hline No & \multicolumn{1}{c}{ Life Cycle Stage } & Debit of Input $\left(\mathbf{m}^{3}\right)$ & Debit of Output $\left(\mathbf{m}^{3}\right)$ \\
\hline \hline 1 & Influent Box & $2,617,488$ & $2,617,488$ \\
2 & Screw Pump & $2,617,488$ & $2,617,488$ \\
3 & Screening & $2,617,488$ & $2,617,488$ \\
4 & Grit Chamber & $2,617,488$ & $2,617,488$ \\
5 & Splitter Box & $2,617,488$ & $2,239,056$ \\
6 & UASB Reactor & $2,239,056$ & $2,428,272$ \\
7 & Skimming Tank & $2,428,272$ & $2,428,272$ \\
8 & Aerated Pond & $2,428,272$ & $5,234,976$ \\
9 & Facultative Pond & $5,234,976$ & $3,901,011$ \\
10 & Release of Wastewater Effluent & $3,901,011$ & $3,901,011$ \\
\hline
\end{tabular}

Table 6. LCI of Wastewater Constituents

\begin{tabular}{|c|c|c|c|c|c|c|c|c|c|c|c|c|}
\hline No & Substance & Unit & $\begin{array}{c}\text { Influent } \\
\text { Box }\end{array}$ & $\begin{array}{l}\text { Screw } \\
\text { Pump }\end{array}$ & Screening & $\begin{array}{c}\text { Grit } \\
\text { Chamber }\end{array}$ & $\begin{array}{l}\text { Splitter } \\
\text { Box }\end{array}$ & $\begin{array}{l}\text { UASB } \\
\text { Reactor }\end{array}$ & $\begin{array}{c}\text { Skimming } \\
\text { Tank }\end{array}$ & $\begin{array}{c}\text { Aerated } \\
\text { Pond }\end{array}$ & $\begin{array}{l}\text { Facultative } \\
\text { Pond }\end{array}$ & $\begin{array}{c}\text { Release of } \\
\text { Wastewater Effluent }\end{array}$ \\
\hline 1 & Biological Oxygen Demand (BOD) & $\mathrm{kg}$ & 853,301 & 819,274 & 764,306 & 602,022 & 552,290 & 378,400 & 369,097 & 354,528 & 199,976 & 87,383 \\
\hline 2 & Chemical oxigen demand (COD) & $\mathrm{kg}$ & $1,672,575$ & $1,672,575$ & $1,502,438$ & $1,232,837$ & $1,128,137$ & 745,606 & 752,764 & 699,342 & 408,328 & 171,644 \\
\hline 3 & TDS & $\mathrm{kg}$ & 840,214 & 785,246 & 664,842 & 607,257 & 463,295 & 219,427 & 80,133 & 67,992 & 16,804 & 4,330 \\
\hline 4 & ss & $\mathrm{kg}$ & $2,607,018$ & $2,114,930$ & $1,913,384$ & $1,565,258$ & $1,117,667$ & 620,219 & 242,827 & 201,547 & 94,230 & 39,010 \\
\hline 5 & TSS & $\mathrm{kg}$ & $1,468,411$ & 840,214 & 785,246 & 523,498 & 523,498 & 369,444 & 140,840 & 133,555 & 52,350 & 19,505 \\
\hline 6 & Ammonia $\left(\mathrm{NH}_{3}\right)$ & $\mathrm{kg}$ & 69,625 & 52,612 & 46,330 & 46,330 & 37,692 & 32,242 & 24,526 & 22,826 & 16,857 & 6,983 \\
\hline 7 & Ammonium $\left(\mathrm{NH}^{4+}\right)$ & $\mathrm{kg}$ & 84,545 & 67,531 & 59,417 & 59,417 & 48,424 & 41,423 & 31,568 & 29,382 & 21,673 & 9,011 \\
\hline 8 & Carbon Disulfide $\left(\mathrm{CS}_{2}\right)$ & $\mathrm{kg}$ & 4,345 & 4,345 & 2,644 & 2,644 & 2,879 & 2,463 & 2,428 & 2,185 & 523 & 390 \\
\hline 9 & Hydrogen Fluoride (HF) & $\mathrm{kg}$ & 2,617 & 2,617 & 2,617 & 2,617 & 2,617 & 2,239 & 2,428 & 2,428 & 1,570 & 780 \\
\hline 10 & Nitrate $\left(\mathrm{NO}^{3}\right)$ & $\mathrm{kg}$ & 4,973 & 4,973 & 3,926 & 3,926 & 3,141 & 2,687 & 2,671 & 2,428 & 523 & 390 \\
\hline 11 & Nitric Acid $\left(\mathrm{HNO}_{3}\right)$ & $\mathrm{kg}$ & 2,094 & 1,832 & 1,832 & 1,832 & 1,832 & 1,567 & 1,214 & 1,943 & 1,047 & 780 \\
\hline 12 & Nitrite $\left(\mathrm{NO}^{2}\right)$ & $\mathrm{kg}$ & 2,332 & 2,332 & 2,233 & 2,233 & 2,233 & 1,910 & 1,824 & 2,382 & 136 & 74 \\
\hline 13 & Nitrogen $(\mathrm{N})$ & $\mathrm{kg}$ & 172,754 & 143,962 & 86,377 & 86,377 & 86,377 & 73,889 & 43,709 & 48,565 & 52,350 & 15,604 \\
\hline 14 & Phosphate $\left(\mathrm{PO}_{4}^{3}\right)$ & $\mathrm{kg}$ & 5,209 & 5,444 & 4,057 & 4,057 & 4,057 & 3,471 & 2,914 & 2,914 & 476 & 355 \\
\hline 15 & Phosphoric Acid $\left(\mathrm{H}_{3} \mathrm{PO}_{4}\right)$ & $\mathrm{kg}$ & 7,329 & 6,805 & 5,235 & 5,235 & 2,617 & 2,239 & 3,157 & 2,671 & 52 & 39 \\
\hline 16 & Phosphorus (P) & $\mathrm{kg}$ & 1,675 & 2,199 & 1,309 & 1,309 & 1,309 & 1,120 & 947 & 1,068 & 152 & 113 \\
\hline 17 & Chromium (VI) ion $\left(\mathrm{Cr}^{6+}\right)$ & $\mathrm{kg}$ & 628 & 628 & 497 & 497 & 419 & 381 & 413 & 243 & 52 & 39 \\
\hline
\end{tabular}


Table 7. LCI of Sludge Production

\begin{tabular}{clccl}
\hline No & Life Cycle Stage & Sludge Production & Unit & Note \\
\hline \hline 1 & Screening & 57.58 & $\mathrm{~m}^{3}$ & Residual production of preliminary treatment \\
2 & Grit Chamber & 266.98 & $\mathrm{~m}^{3}$ & Residual production of preliminary treatment \\
\hline 1 & UASB Reactor & 111,841 & $\mathrm{kgSS}$ & Sludge production of secondary treatment \\
2 & Aerated Pond & 209,803 & $\mathrm{kgSS}$ & Sludge production of secondary treatment \\
3 & Facultative Pond & 89,832 & $\mathrm{kgSS}$ & Sludge production of secondary treatment \\
\hline 1 & Sludge Drying Beds & 105,130 & $\mathrm{kgSS}$ & Dewatered sludge production \\
\hline
\end{tabular}

Table 8. LCI of Dry Sludge Constituents

\begin{tabular}{|c|c|c|c|c|}
\hline No & Life Cycle Stage & Dry Sludge Amount (kg) & Substance & Mass (kg) \\
\hline \multirow{17}{*}{1} & \multirow{17}{*}{ Disposal of Dry Sludge } & \multirow{17}{*}{105,130} & Nitrogen $(\mathrm{N})$ & 1.E-02 \\
\hline & & & Phosphorus (P) & 2.E-03 \\
\hline & & & Phosphorus(V)oxide $\left(\mathrm{P}_{2} \mathrm{O}_{5}\right)$ & 3.E-03 \\
\hline & & & Arsenic (V) ion $\left(\mathrm{As}^{5+}\right)$ & 3.E-07 \\
\hline & & & Cadmium (II) ion $\left(\mathrm{Cd}^{2+}\right)$ & 1.E-05 \\
\hline & & & Chromium (III) ion $\left(\mathrm{Cr}^{3+}\right)$ & 5.E-05 \\
\hline & & & Chromium (VI) ion $\left(\mathrm{Cr}^{6+}\right)$ & 8.E-04 \\
\hline & & & Cobalt $(\mathrm{Co})$ & 3.E-07 \\
\hline & & & Copper (II) ion $\left(\mathrm{CuH}_{4}{ }^{2+}\right)$ & 1.E-05 \\
\hline & & & Lead (II) ion $\left(\mathrm{Pb}^{2+}\right)$ & 3.E-05 \\
\hline & & & Mercury (II) ion $\left(\mathrm{Hg}^{2+}\right)$ & 3.E-07 \\
\hline & & & Methyl-mercury $\left(\mathrm{CH}_{3} \mathrm{Hg}^{+}\right)$ & 3.E-07 \\
\hline & & & Molybdenum (Mo) & 3.E-07 \\
\hline & & & Nickel (II) ion $\left(\mathrm{Ni}^{2+}\right)$ & 3.E-05 \\
\hline & & & Selenium (Se) & 3.E-07 \\
\hline & & & Zinc (II) ion $\left(\mathrm{Zn}^{2+}\right)$ & 5.E-05 \\
\hline & & & Carbondioxide $\left(\mathrm{CO}_{2}\right)$ & 4.E+04 \\
\hline
\end{tabular}

Table 9. LCI of Electricity Use

\begin{tabular}{|c|c|c|c|c|c|}
\hline No & Life Cycle Stage & Electricity Use (kWh) & $\mathrm{CO}_{2}$ Emission $\left(\mathrm{kgCO}_{2 \text {-eq }}\right)$ & $\mathrm{CH}_{4}$ Emission $\left(\mathrm{kgCH}_{4 \mathrm{eq}}\right)$ & $\mathrm{N}_{2} \mathrm{O}$ Emission (kgN $\mathrm{kg}_{2} \mathrm{O}$-eq.) \\
\hline 1 & Screw Pump & 116,455 & 79,736 & 1.64 & 0.90 \\
\hline 2 & Screening & 4,134 & 2,830 & 0.06 & 0.03 \\
\hline 3 & Grit Chamber & 10,776 & 7,378 & 0.15 & 0.08 \\
\hline 4 & Sludge Drying Beds & 2,880 & 1,972 & 0.04 & 0.02 \\
\hline 5 & Aerated Pond & 112,834 & 77,257 & 1.59 & 0.87 \\
\hline & Total & 247,078 & 169,174 & 3.48 & 1.92 \\
\hline
\end{tabular}

Table 10. LCI of Diesel Consumption

\begin{tabular}{clcc}
\hline No & Life Cycle Stage & Diesel Consumption (kg) & $\mathbf{C O}_{2}$ Emission (kgCO $\mathbf{C O}_{2}$-eq.) \\
\hline \hline 1 & Screw Pump & 137,064 & 446,400 \\
2 & Screening & 4,865 & 15,846 \\
3 & Grit Chamber & 12,683 & 41,307 \\
4 & Sludge Drying Beds & 3,390 & 11,040 \\
5 & Aerated Pond & 132,802 & 432,520 \\
\hline & Total & $\mathbf{2 9 0 , 8 0 4}$ & $\mathbf{9 4 7 , 1 1 2}$ \\
\hline
\end{tabular}


Table 11. LCI of Oxygen Consumption of Aerator

\begin{tabular}{ccc}
\hline No & Life Cycle Stage & Oxygen Consumption (kg) \\
\hline \hline 1 & Aerated Pond & 183,226 \\
\hline
\end{tabular}

Table 12. LCI of Biogenic Emission

\begin{tabular}{|c|c|c|c|c|}
\hline No & Life Cycle Stage & $\mathrm{CO}_{2}$ Emission $\left(\mathrm{kgCO}_{2-\text {-eq }}\right)$ & $\mathrm{CH}_{4}$ Emission $\left(\mathrm{kgCH}_{4-\mathrm{eq}}\right)$ & $\mathrm{N}_{2} \mathrm{O}$ Emission ( $\mathrm{kgN}_{2} \mathrm{O}$-eq.) \\
\hline 1 & Aerated Pond & 126,255 & 0 & 410 \\
\hline 2 & Facultative Pond & 54,113 & 21,317 & 303 \\
\hline 3 & UASB Reactor & 22,477 & 8,855 & 579 \\
\hline
\end{tabular}

Table 13. LCI of Lubricant Consumption

\begin{tabular}{clccc}
\hline No & Life Cycle Stage & Lubricant Consumption (kg) & $\mathbf{C O}_{2}$ Emission (kgCO & -eq.) Percentage \\
\hline \hline 1 & Screw Pump & 2,129 & 1,276 & $47 \%$ \\
2 & Screening & 75 & 45 & $2 \%$ \\
3 & Grit Chamber & 202 & 121 & $4 \%$ \\
4 & Sludge Drying Beds & 52 & 31 & $1 \%$ \\
5 & Aerated Pond & 2,041 & 1,223 & $45 \%$ \\
\hline Total & & $\mathbf{4 , 5 0 0}$ & $\mathbf{2 6 9 7}$ & $\mathbf{1 0 0 \%}$ \\
\hline Lubricant Residue & $\mathbf{3 6 0 0}$ & & \\
Lubricant Spill & $\mathbf{1 8 0}$ & & \\
\hline
\end{tabular}

Table 14. LCI of Lubricant Element Concentration

\begin{tabular}{|c|c|c|c|c|}
\hline No & Life Cycle Stage & Lubricant Consumption (kg) & Substance & Mass (kg) \\
\hline \multirow{7}{*}{1} & \multirow{7}{*}{ Screw Pump } & \multirow{7}{*}{ " } & Arsenic (V) ion $\left(\mathrm{As}^{5+}\right)$ & 0.02350046 \\
\hline & & & Cadmium (II) ion $\left(\mathrm{Cd}^{2+}\right)$ & 0.02716571 \\
\hline & & & Cobalt $(\mathrm{Co})$ & 0.00000031 \\
\hline & & & Molybdenum (Mo) & 0.07102692 \\
\hline & & & Nickel (II) ion $\left(\mathrm{Ni}^{2+}\right)$ & 0.00734302 \\
\hline & & & Lead (II) ion $\left(\mathrm{Pb}^{2+}\right)$ & 0.00022632 \\
\hline & & & Zinc (II) ion $\left(\mathrm{Zn}^{2+}\right)$ & 4.43878769 \\
\hline \multirow{7}{*}{2} & \multirow{7}{*}{ Screening } & \multirow{7}{*}{3} & Arsenic (V) ion $\left(\mathrm{As}^{5+}\right)$ & 0.00082540 \\
\hline & & & Cadmium (II) ion $\left(\mathrm{Cd}^{2+}\right)$ & 0.00095413 \\
\hline & & & Cobalt $(\mathrm{Co})$ & 0.00000001 \\
\hline & & & Molybdenum (Mo) & 0.00249466 \\
\hline & & & Nickel (II) ion $\left(\mathrm{Ni}^{2+}\right)$ & 0.00025791 \\
\hline & & & Lead (II) ion $\left(\mathrm{Pb}^{2+}\right)$ & 0.00000795 \\
\hline & & & Zinc (II) ion $\left(\mathrm{Zn}^{2+}\right)$ & 0.15590227 \\
\hline \multirow{7}{*}{3} & \multirow{7}{*}{ Grit Chamber } & \multirow{7}{*}{8} & Arsenic (V) ion $\left(\mathrm{As}^{5+}\right)$ & 0.00223105 \\
\hline & & & Cadmium (II) ion $\left(\mathrm{Cd}^{2+}\right)$ & 0.00257901 \\
\hline & & & Cobalt (Co) & 0.00000003 \\
\hline & & & Molybdenum (Mo) & 0.00674303 \\
\hline & & & Nickel (II) ion $\left(\mathrm{Ni}^{2+}\right)$ & 0.00069712 \\
\hline & & & Lead (II) ion $\left(\mathrm{Pb}^{2+}\right)$ & 0.00002149 \\
\hline & & & Zinc (II) ion $\left(\mathrm{Zn}^{2+}\right)$ & 0.42140207 \\
\hline \multirow{7}{*}{4} & \multirow{7}{*}{ Sludge Drying Beds } & \multirow{7}{*}{2} & Arsenic $(\mathrm{V})$ ion $\left(\mathrm{As}^{5+}\right)$ & 0.00057504 \\
\hline & & & Cadmium (II) ion $\left(\mathrm{Cd}^{2+}\right)$ & 0.00066473 \\
\hline & & & Cobalt (Co) & 0.00000001 \\
\hline & & & Molybdenum (Mo) & 0.00173798 \\
\hline & & & Nickel (II) ion $\left(\mathrm{Ni}^{2+}\right)$ & 0.00017968 \\
\hline & & & Lead (II) ion $\left(\mathrm{Pb}^{2+}\right)$ & 0.00000554 \\
\hline & & & Zinc (II) ion $\left(\mathrm{Zn}^{2+}\right)$ & 0.10861431 \\
\hline \multirow{7}{*}{5} & \multirow{7}{*}{ Aerated Pond } & \multirow{7}{*}{82} & Arsenic $(\mathrm{V})$ ion $\left(\mathrm{As}^{5+}\right)$ & 0.02252916 \\
\hline & & & Cadmium (II) ion $\left(\mathrm{Cd}^{2+}\right)$ & 0.02604292 \\
\hline & & & Cobalt (Co) & 0.00000030 \\
\hline & & & Molybdenum (Mo) & 0.06809130 \\
\hline & & & Nickel (II) ion $\left(\mathrm{Ni}^{2+}\right)$ & 0.00703953 \\
\hline & & & Lead (II) ion $\left(\mathrm{Pb}^{2+}\right)$ & 0.00021697 \\
\hline & & & Zinc (II) ion $\left(\mathrm{Zn}^{2+}\right)$ & 4.25532766 \\
\hline
\end{tabular}


Analysis of Environmental Impacts Based on Life Cycle Stage

Normalization stage makes these impact categories into the same unit therefore comparison between impacts categories are able to do. These impact categories are analyzed in each life cycle stage and a whole system.

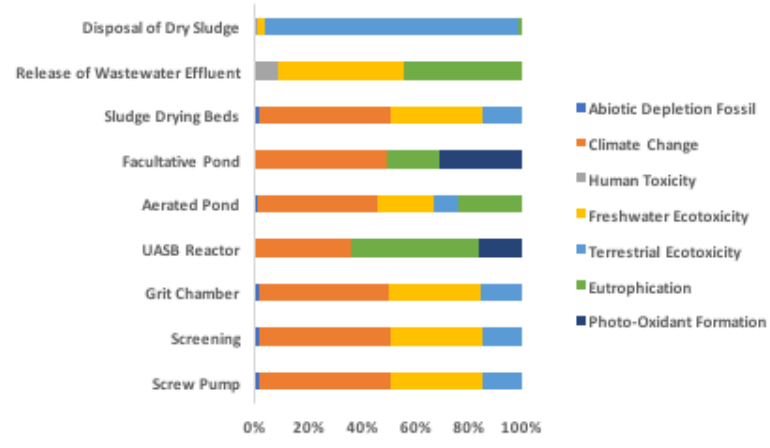

Fig. 7. Analysis Environmental Impacts Based on Life Cycle Stage

- The majority impacts of Screw Pump operational are Climate Change (49.15\%), Freshwater Ecotoxicity (34.13\%), and Terrestrial Ecotoxicity (15.13\%). Climate Change caused by electricity use and diesel consumption, Freshwater and Terrestrial Ecotoxicity caused by lubricant spill of lubricant consumption.

- The majority impacts of Screening operational are Climate Change (49.40\%), Freshwater Ecotoxicity (33.94\%), and Terrestrial Ecotoxicity (15.05\%). Climate Change caused by electricity use and diesel consumption, Freshwater and Terrestrial Ecotoxicity caused by lubricant spill of lubricant consumption.

- The majority impacts of Grit Chamber operational are Climate Change (48.52\%), Freshwater Ecotoxicity (34.57\%), and Terrestrial Ecotoxicity (15.33\%). Climate Change caused by electricity use and diesel consumption, Freshwater and Terrestrial
Ecotoxicity caused by lubricant spill of lubricant consumption.

- The impacts of UASB Reactor operational are Eutrophication (48\%), Climate Change (36\%), and Photo-Oxidant Formation (16\%). These 3 impacts are caused by biogenic emission.

- The majority impacts of Aerated Pond are Climate Change (44.62\%), Eutrophication (24.15\%), Freshwater Ecotoxicity (20.99\%), and Terrestrial Ecotoxicity (9.30\%). Climate Change caused by electricity use, diesel consumption, and biogenic emission, Freshwater and Terrestrial Ecotoxicity caused by lubricant spill of lubricant consumption.

- The impacts of Facultative Pond operational are Climate Change (49\%), Photo-Oxidant Formation (31\%), and Eutrophication (20\%). These 3 impacts are caused by biogenic emission.

- The majority impacts of Sludge Drying Beds operational are Climate Change (49.40\%), Freshwater Ecotoxicity (33.94\%), and Terrestrial Ecotoxicity (15.05\%). Climate Change caused by electricity use and diesel consumption, Freshwater and Terrestrial Ecotoxicity caused by lubricant spill of lubricant consumption.

- The majority impacts of Release of Wastewater Effluent are Freshwater Ecotoxicity (47.06\%) and Eutrophication (44.77\%). These impacts caused by the constituents of wastewater effluent.

- The majority impact of Disposal of Dry Sludge is Terrestrial Ecotoxicity (95.32\%). This impact caused by the constituents of dry sludge. 
Table 15. Normalization Result per Life Cycle Stage

\begin{tabular}{|c|c|c|c|c|c|c|c|c|}
\hline \multirow[t]{2}{*}{ No } & \multirow[t]{2}{*}{$\begin{array}{l}\text { Life Cycle } \\
\text { Stage }\end{array}$} & \multirow{2}{*}{$\begin{array}{c}\text { Impact Category } \\
\text { Abiotic Depletion Fossil }\end{array}$} & \multicolumn{2}{|c|}{ Result of Life Cycle Impact Assessment } & \multicolumn{2}{|c|}{ Normalisation Factor } & \multirow{2}{*}{$\begin{array}{c}\begin{array}{c}\text { Normalized Impact } \\
\text { Category (yr) }\end{array} \\
3.6 \mathrm{E}-10\end{array}$} & \multirow{2}{*}{$\begin{array}{c}\text { Percentage (\%) } \\
1.40 \%\end{array}$} \\
\hline & & & $2.8 \mathrm{E}+03$ & kgantimony-eq. & $7.8 \mathrm{E}+12$ & kgSb-eq. & & \\
\hline \multirow{6}{*}{1} & \multirow{6}{*}{ Screw Pump } & Climate Change & $5.3 \mathrm{E}+05$ & $\mathrm{kgCO}_{2}$-eq. & $4.2 \mathrm{E}+13$ & $\mathrm{kgCO}_{2}$-eq. & $1.3 \mathrm{E}-08$ & $49.15 \%$ \\
\hline & & Human Toxicity & $2.5 \mathrm{E}+02$ & kg1,4-dichlorobenzene-eq. & $8.9 \mathrm{E}+12$ & kg1,4-dichlorobenzene-eq. & $2.8 \mathrm{E}-11$ & $0.11 \%$ \\
\hline & & Freshwater Ecotoxicity & $2.7 \mathrm{E}+02$ & kg1,4-dichlorobenzene-eq. & $3.1 \mathrm{E}+10$ & kg1,4-dichlorobenzene-eq & $8.7 \mathrm{E}-09$ & $34.13 \%$ \\
\hline & & Terrestrial Ecotoxicity & $2.0 \mathrm{E}+02$ & kg1,4-dichlorobenzene-eq. & $5.1 \mathrm{E}+10$ & kg1,4-dichlorobenzene-eq & $3.9 \mathrm{E}-09$ & $15.13 \%$ \\
\hline & & Eutrophication & $2.4 \mathrm{E}-01$ & $\mathrm{kgPO}_{4}$-eq- & $3.8 \mathrm{E}+09$ & $\mathrm{kgP}-\mathrm{eq}$ & 2.1E-11 & $0.08 \%$ \\
\hline & & Photo-Oxidant Formation & 9.8E-03 & kgethylene-eq. & $2.8 \mathrm{E}+10$ & kgNMVOC-eq. & 8.5E-13 & $0.00 \%$ \\
\hline \multicolumn{7}{|c|}{ Total } & $2.6 \mathrm{E}-08$ & $100 \%$ \\
\hline \multirow{8}{*}{2} & \multirow{7}{*}{ Screening } & Abiotic Depletion Fossil & $9.9 \mathrm{E}+01$ & kgantimony-eq. & $7.8 \mathrm{E}+12$ & kgSb-eq. & $1.3 \mathrm{E}-11$ & $1.41 \%$ \\
\hline & & Climate Change & $1.9 \mathrm{E}+04$ & $\mathrm{kgCO}_{2}$-eq. & $4.2 \mathrm{E}+13$ & $\mathrm{kgCO}_{2}$-eq. & $4.4 \mathrm{E}-10$ & $49.40 \%$ \\
\hline & & Human Toxicity & $8.7 \mathrm{E}+00$ & kg1,4-dichlorobenzene-eq. & $8.9 \mathrm{E}+12$ & $\mathrm{kgl}$ 1-dichlorobenzene-eq. & $9.8 \mathrm{E}-13$ & $0.11 \%$ \\
\hline & & Freshwater Ecotoxicity & $9.4 \mathrm{E}+00$ & kg1,4-dichlorobenzene-eq. & $3.1 \mathrm{E}+10$ & kg1,4-dichlorobenzene-eq & $3.1 \mathrm{E}-10$ & $33.94 \%$ \\
\hline & & Terrestrial Ecotoxicity & $6.9 \mathrm{E}+00$ & kg1,4-dichlorobenzene-eq. & $5.1 \mathrm{E}+10$ & kgl,4-dichlorobenzene-eq & $1.4 \mathrm{E}-10$ & $15.05 \%$ \\
\hline & & Eutrophication & $8.7 \mathrm{E}-03$ & $\mathrm{kgPO}_{4}$ eq. & $3.8 \mathrm{E}+09$ & $\mathrm{kgP}-\mathrm{eq}$. & $7.5 \mathrm{E}-13$ & $0.08 \%$ \\
\hline & & Photo-Oxidant Formation & $3.5 \mathrm{E}-04$ & kgethylene-eq. & $2.8 \mathrm{E}+10$ & kgNMVOC-eq. & $3.0 \mathrm{E}-14$ & $0.00 \%$ \\
\hline & \multicolumn{6}{|c|}{ Total } & $9.0 \mathrm{E}-10$ & $100 \%$ \\
\hline \multirow{7}{*}{3} & \multirow{7}{*}{ Grit Chamber } & Abiotic Depletion Fossil & $2.6 \mathrm{E}+02$ & kgantimony-eq. & $7.8 \mathrm{E}+12$ & kgSb-eq. & 3.3E-11 & $1.39 \%$ \\
\hline & & Climate Change & $4.9 \mathrm{E}+04$ & $\mathrm{kgCO}_{2}$-eq. & $4.2 \mathrm{E}+13$ & $\mathrm{kgCO}_{2}$ eq. & $1.2 \mathrm{E}-09$ & $48.52 \%$ \\
\hline & & Human Toxicity & $2.3 \mathrm{E}+01$ & kgl,4-dichlorobenzene-eq. & $8.9 \mathrm{E}+12$ & $\mathrm{kgl}$,4-dichlorobenzene-eq. & 2.6E-12 & $0.11 \%$ \\
\hline & & Freshwater Ecotoxicity & $2.5 \mathrm{E}+01$ & kg1,4-dichlorobenzene-eq. & $3.1 \mathrm{E}+10$ & kg1,4-dichlorobenzene-eq & $8.3 \mathrm{E}-10$ & $34.57 \%$ \\
\hline & & Terrestrial Ecotoxicity & $1.9 \mathrm{E}+01$ & kg1,4-dichlorobenzene-eq. & $5.1 \mathrm{E}+10$ & kg1,4-dichlorobenzene-eq & $3.7 \mathrm{E}-10$ & $15.33 \%$ \\
\hline & & Eutrophication & $2.3 \mathrm{E}-02$ & $\mathrm{kgPO}_{4} \mathrm{eq}$ & $3.8 \mathrm{E}+09$ & $\mathrm{kgP}-\mathrm{eq}$. & $2.0 \mathrm{E}-12$ & $0.08 \%$ \\
\hline & & Photo-Oxidant Formation & 9.1E-04 & kgethylene-eq. & $2.8 \mathrm{E}+10$ & kgNMVOC-eq. & $7.8 \mathrm{E}-14$ & $0.00 \%$ \\
\hline & & & & otal & & & $2.4 \mathrm{E}-09$ & $100 \%$ \\
\hline & & Climate Change & $4.2 \mathrm{E}+0.5$ & $\mathrm{kgCO}_{2}$-eq. & $4.2 \mathrm{E}+13$ & $\mathrm{kgCO}_{2}$-eq- & $1.0 \mathrm{E}-08$ & $36 \%$ \\
\hline 4 & $\begin{array}{l}\text { UASB } \\
\text { Reactor }\end{array}$ & Eutrophication & $1.6 \mathrm{E}+02$ & $\mathrm{kgPO}_{4}$ eq. & $3.8 \mathrm{E}+09$ & kgP-eq. & $1.4 \mathrm{E}-08$ & $48 \%$ \\
\hline & & Photo-Oxidant Formation & $5.3 \mathrm{E}+(0) 1$ & kgethylene-eq. & $2.8 \mathrm{E}+10$ & kgNMVOC-eq. & 4.6E- -09 & $16 \%$ \\
\hline & & & & otal & & & $2.8 \mathrm{E}-08$ & $100 \%$ \\
\hline & & Abiotic Depletion Fossil & $2.7 \mathrm{E}+03$ & kgantimony-eq. & $7.8 \mathrm{E}+12$ & kgSb-eq. & $3.5 \mathrm{E}-10$ & $0.873 \%$ \\
\hline & & Climate Change & $7.5 \mathrm{E}+05$ & $\mathrm{kgCO}_{2}$-eq. & $4.2 \mathrm{E}+13$ & $\mathrm{kgCO}_{2}$-eq. & $1.8 \mathrm{E}-08$ & $44.615 \%$ \\
\hline & & Human Toxicity & $2.4 \mathrm{E}+02$ & kg1,4-dichlorobenzene-eq. & $8.9 \mathrm{E}+12$ & $\mathrm{kgl}$-4-dichlorobenzene-eq. & 2.7E-11 & $0.07 \%$ \\
\hline 5 & Acrated Pond & Freshwater Ecotoxicity & $2.6 \mathrm{E}+02$ & kg1,4-dichlorobenzene-eq. & $3.1 \mathrm{E}+10$ & kg1,4-dichlorobenzene-eq & $8.3 \mathrm{E}-09$ & $20.99 \%$ \\
\hline & & Terrestrial Ecotoxicity & $1.9 \mathrm{E}+02$ & kg1,4-dichlorobenzene-eq. & $5.1 \mathrm{E}+10$ & kg1,4-dichlorobenzene-eq & 3.7E-09 & $9.30 \%$ \\
\hline & & Eutrophication & $1.1 \mathrm{E}+02$ & $\mathrm{kgPO}_{4}$ eq. & $3.8 \mathrm{E}+09$ & kgP-eq. & $9.6 \mathrm{E}-09$ & $24.154 \%$ \\
\hline & & Photo-Oxidant Formation & $9.5 \mathrm{E}-03$ & kgethylene-eq. & $2.8 \mathrm{E}+10$ & kgNMVOC-eq. & $8.2 \mathrm{E}-13$ & $0.002 \%$ \\
\hline & & & & otal & & & $4.0 \mathrm{E}-08$ & $100 \%$ \\
\hline & & Climate Change & $7.3 \mathrm{E}+05$ & $\mathrm{kgCO}_{2}$-eq. & $4.2 \mathrm{E}+13$ & $\mathrm{kgCO}_{2}$-eq. & $1.7 \mathrm{E}-08$ & $49 \%$ \\
\hline 6 & $\begin{array}{l}\text { Facultative } \\
\text { Pond }\end{array}$ & Eutrophication & $8.2 \mathrm{E}+01$ & $\mathrm{kgPO}_{4}-\mathrm{eq}$ & $3.8 \mathrm{E}+(09$ & $\mathrm{kgP}-\mathrm{eq}$. & $7.1 \mathrm{E}-09$ & $20 \%$ \\
\hline & & Photo-Oxidant Formation & $1.3 \mathrm{E}+02$ & kgethylene-eq. & $2.8 \mathrm{E}+10$ & kgNMVOC-eq. & $1.1 \mathrm{E}-08$ & $31 \%$ \\
\hline & & & & otal & & & $3.5 \mathrm{E}-08$ & $100 \%$ \\
\hline & & Abiotic Depletion Fossil & $6.9 \mathrm{E}+01$ & kgantimony-eq. & $7.8 \mathrm{E}+12$ & kgSb-eq. & $8.9 \mathrm{E}-12$ & $1.41 \%$ \\
\hline & & Climate Change & $1.3 \mathrm{E}+04$ & $\mathrm{kgCO}_{2}$-eq. & $4.2 \mathrm{E}+13$ & $\mathrm{kgCO}_{2}$-eq. & $3.1 \mathrm{E}-10$ & $49.40 \%$ \\
\hline & & Human Toxicity & $6.0 \mathrm{E}+(00)$ & kg1,4-dichlorobenzene-eq. & $8.9 \mathrm{E}+12$ & $\mathrm{kgl}$ 1,4-dichlorobenzene-eq. & $6.8 \mathrm{E}-13$ & $0.11 \%$ \\
\hline 7 & $\begin{array}{l}\text { Sludge Drying } \\
\text { Beds }\end{array}$ & Freshwater Ecotoxicity & $6.5 \mathrm{E}+00$ & kg1,4-dichlorobenzene-eq. & $3.1 \mathrm{E}+10$ & kg1,4-dichlorobenzene-eq & $2.1 \mathrm{E}-10$ & $33.94 \%$ \\
\hline & & Terrestrial Ecotoxicity & $4.8 \mathrm{E}+00$ & kg1,4-dichlorobenzene-eq. & $5.1 \mathrm{E}+10$ & kg1,4-dichlorobenzene-eq & $9.4 \mathrm{E}-11$ & $15.05 \%$ \\
\hline & & Eutrophication & $6.0 \mathrm{E}-03$ & $\mathrm{kgPO}_{4}$-eq. & $3.8 \mathrm{E}+(199$ & $\mathrm{kgP}-\mathrm{eq}$. & $5.2 \mathrm{E}-13$ & $0.08 \%$ \\
\hline & & Photo-Oxidant Formation & $2.4 \mathrm{E}-04$ & kgethylene-eq. & $2.8 \mathrm{E}+10$ & kgNMVOC-eq. & 2.1E-14 & $0.00 \%$ \\
\hline & & & & otal & & & $6.3 \mathrm{E}-10$ & $100 \%$ \\
\hline & & Human Toxicity & $2.8 \mathrm{E}+0.6$ & $\mathrm{~kg}$ 1,4-dichlorobenzene-eq. & $8.9 \mathrm{E}+12$ & $\mathrm{kgl}$ 1,4-dichlorobenzene-eq. & $3.2 \mathrm{E}-07$ & $8.163043 \%$ \\
\hline 8 & $\begin{array}{l}\text { Release of } \\
\text { Wastewater }\end{array}$ & Freshwater Ecotoxicity & $5.7 \mathrm{E}+04$ & kg1,4-dichlorobenzene-eq. & $3.1 \mathrm{E}+10$ & kgl,4-dichlorobenzene-eq & $1.8 \mathrm{E}-06$ & $47.063386 \%$ \\
\hline 8 & $\begin{array}{l}\text { Wastewater } \\
\text { Effluent }\end{array}$ & Terrestrial Ecotoxicity & $1.9 \mathrm{E}+00$ & $\mathrm{~kg} 1,4$-dichlorobenzene-eq. & $5.1 \mathrm{E}+10$ & $\mathrm{kg1,4-dichlorobenzene-eq.}$ & $3.8 \mathrm{E}-11$ & $0.000955 \%$ \\
\hline & & Eutrophication & $2.0 \mathrm{E}+04$ & $\mathrm{kgPO}_{4}$ eq. & $3.8 \mathrm{E}+09$ & kgP-eq. & $1.8 \mathrm{E}-06$ & $44.772616 \%$ \\
\hline & & & & otal & & & $3.9 \mathrm{E}-06$ & $100 \%$ \\
\hline & & Human Toxicity & $7.4 \mathrm{E}+00$ & kg1,4-dichlorobenzene-eq. & $8.9 \mathrm{E}+12$ & $\mathrm{kgl}$ 1,-dichlorobenzene-eq. & $8.3 \mathrm{E}-13$ & $0.761 \%$ \\
\hline 9 & Disposal of & Freshwater Ecotoxicity & $8.7 \mathrm{E}-02$ & $\mathrm{kgl}$ 1,4-dichlorobenzene-eq. & $3.1 \mathrm{E}+10$ & $\mathrm{kg1,4-dichlorobenzene-eq.}$ & $2.8 \mathrm{E}-12$ & $2.592 \%$ \\
\hline & Dry Sludge & Terrestrial Ecotoxicity & $5.3 \mathrm{E}+00$ & kg1,4-dichlorobenzene-eq. & $5.1 \mathrm{E}+10$ & kg1,4-dichlorobenzene-eq & $1.0 \mathrm{E}-10$ & $95.317 \%$ \\
\hline & & Eutrophication & $1.7 \mathrm{E}-02$ & $\mathrm{kgPO}_{4}$-eq. & $3.8 \mathrm{E}+09$ & $\mathrm{kgP}-\mathrm{eq}$. & $1.4 \mathrm{E}-12$ & $1.330 \%$ \\
\hline & & & & otal & & & $1.1 \mathrm{E}-10$ & $100 \%$ \\
\hline
\end{tabular}


Analysis of Normalization Result for a Whole System of IPAL Cemara

According to the normalization result, the analysis of a whole system of IPAL Cemara is able to do. This is analysis of the normalized by impact category and another one is analysis of the normalized by life cycle stage.

Table 16. and Figure 8 display the normalized by impact category of IPAL Cemara. The impact category that gives the largest contribution in IPAL Cemara is Freshwater Ecotoxicity (45.96\%) and Eutrophication (44.04\%). Freshwater ecotoxicity dominated by the presence of $\mathrm{CS}_{2}(72 \%)$ at Release of Wastewater Effluent and Eutrophication dominated by $33 \%$ of $\mathrm{NH}_{3}$ and $32 \%$ of $\mathrm{N}$.

Table 4.21. Normalized by Impact Categories of IPAL Cemara

\begin{tabular}{|c|c|c|c|c|c|}
\hline No & Impact Category & Result of Life Cycle Impact & Normalisation Factor & Normalized Impact Category & Percentage \\
\hline 1 & Abiotic Depletion Fossil & kgantimony-eq. & $7.8 \mathrm{E}+12 \mathrm{kgSb}-\mathrm{eq}$ & $7.6 \mathrm{E}-10$ & $0.018707 \%$ \\
\hline 2 & Climate Change & $\mathrm{kgCO}_{2}$-eq. & $4.2 \mathrm{E}+13 \mathrm{kgCO}_{2}-\mathrm{eq}$. & 6.1E-08 & $1.494151 \%$ \\
\hline 3 & Human Toxicity & kg1,4-dichlorobenzene-eq. & 8.9E+12 kgl,4-dichlorobenzene & $3.2 \mathrm{E}-07$ & $7.895350 \%$ \\
\hline 4 & Freshwater Ecotoxicity & kg1,4-dichlorobenzene-eq. & $3.1 \mathrm{E}+10 \mathrm{kgl}, 4$-dichlorobenzen & $1.9 \mathrm{E}-06$ & $45.964445 \%$ \\
\hline 5 & Terrestrial Ecotoxicity & kg1,4-dichlorobenzene-eq. & $5.1 \mathrm{E}+10 \mathrm{~kg} 1,4$-dichlorobenzene & $8.3 \mathrm{E}-09$ & $0.204223 \%$ \\
\hline 6 & Eutrophication & $\mathrm{kgPO}_{4}$-eq. & $3.8 \mathrm{E}+09 \mathrm{kgP}-\mathrm{eq}$. & $1.8 \mathrm{E}-06$ & $44.040414 \%$ \\
\hline 7 & Photo-Oxidant Formation & kgethylene-eq. & $2.8 \mathrm{E}+10 \mathrm{kgNMVOC}-\mathrm{eq}$. & $1.6 \mathrm{E}-08$ & $0.382709 \%$ \\
\hline \multicolumn{4}{|c|}{ Total } & $4.1 \mathrm{E}-06$ & $100 \%$ \\
\hline
\end{tabular}

Whereas based on normalized by Life Cycle Stage, Release of Wastewater Effluent (96.73\%) is the largest contributor on environmental impact. The detail is displayed by table below.

Table 4.22. Normalized by Life Cycle Stage of IPAL Cemara

\begin{tabular}{clcc}
\hline No & \multicolumn{1}{c}{ Life Cycle Stage } & Normalized Impact Category (yr) & Percentage \\
\hline \hline 1 & Screw Pump & $2.6 \mathrm{E}-08$ & $0.628 \%$ \\
2 & Screening & $9.0 \mathrm{E}-10$ & $0.022 \%$ \\
3 & Grit Chamber & $2.4 \mathrm{E}-09$ & $0.059 \%$ \\
4 & UASB Reactor & $2.8 \mathrm{E}-08$ & $0.694 \%$ \\
5 & Aerated Pond & $4.0 \mathrm{E}-08$ & $0.979 \%$ \\
6 & Facultative Pond & $3.5 \mathrm{E}-08$ & $0.873 \%$ \\
7 & Sludge Drying Beds & $6.3 \mathrm{E}-10$ & $0.015 \%$ \\
8 & Release of Wastewater Effluent & $\mathbf{3 . 9 E}-06$ & $96.727 \%$ \\
9 & Disposal of Dry Sludge & $1.1 \mathrm{E}-10$ & $0.003 \%$ \\
\hline \multicolumn{2}{c}{ Total } & $\mathbf{4 . 1 E}-06$ & $\mathbf{1 0 0} \%$ \\
\hline
\end{tabular}

\section{Conclusion}

From this research, there are some conclusions relates to the operational impact of IPAL Cemara on environment :

1. Aerated Pond has removal efficiency of BOD and COD more than $70 \%$, but on the other hand, it is the largest contributor to Climate Change impact because of diesel consumption (16.97\%), the amount of $\mathrm{CO}_{2}(4,95 \%)$, and $\mathrm{N}_{2} \mathrm{O}(4.26 \%)$ from biogenic emission, and electricity use (3.04\%).
2. The $65 \%$ reducing of TSS is occurred in UASB Reactor but UASB Reactor also as contributor for Climate Change impact (16.63\%) and Photo-Oxidant Formation impact $(29.34 \%)$ due to the highest production of $\mathrm{CH}_{4}$.

3. Facultative Pond contributes $49 \%$ of Climate Change impact and $31 \%$ of Photo-Oxydant Formation impact because of the highest production of $\mathrm{CH}_{4}$.

4. Screw Pump and Aerator become the majority of Abiotic Depletion Fossil, Climate Change, 
and Terrestrial Ecotoxicity impact because of the higher consumption of diesel and lubricant, and electricity use. Terrestrial Ecotoxicity caused by the lubricant spill from lubricant residue.

5. Based on normalized by impact category, Freshwater Ecotoxicity and Eutrophication is the largest environmental impact in a whole system of IPAL Cemara. Freshwater Ecotoxicity caused by $72 \% \mathrm{CS}_{2}$ at Release of Wastewater and Eutrophication caused by $41.25 \%$ of $\mathrm{NH}_{3}$ and $39.60 \%$ of N. It is Align with the result of normalized by Life Cycle Stage, shows that the Release of Wastewater Effluent is the largest contributor to environment in a whole system of IPAL Cemara.

\section{Acknowledgement}

Special thank to Mr. Fiza Lubis as Production Head in IPAL Cemara Medan.Thank you for all his precious of time and help. Thank you also to Mr. Faisal, Mr. Fahmi, Dr. Indriyani Rachman, Hafizhul Khair, and Dedi Abdul Hadi.

\section{References}

Australian National Greenhouse Accounts. (2015). Australian National Greenhouse Accounts Factors, Department of Environment, Commonwealth of Australia, $78 \mathrm{p}$.

Brander, M.,Sood, A., Wylie, C., Haughton, A., Lovell, J. (2011). Electricity-specific emission factors for grid electricity. Technical paper, Ecometrica, 22 p.

Foley, J., de Haas, D., Hartley, K., Lant, P. (2010). Comprehenshive life cycle inventories of alternative wastewater treatment systems. Water Research, 44(5), 1654-1666.

Li, Y., Luo, X., Huang, X., Wang, D., Zhang, W. (2013). Life Cycle Assessment of municipal wastewater treatment plant: a case study in Suzhou, China. Journal of Cleaner Production, 57, 221-227.
Mcnamara, G., Fitzsimons, L., Horrigan, M., Phelan, T., Delaure, Y., Corcoran, B., Doherty, E., Clifford, E. (2016). Life Cycle Assessment of Waste Water Treatment Plant in Ireland. Journal of Sustainable Development of Energy, Water and Environment System, 4(3), 216-233.

N.C. RTI International. (2010, December). Greenhouse Gas Emissions Estimation Methodologies for Biogenic Emissions from Selected Source Categories : Solid Waste Disposal, Wastewater Treatment, Ethanol Fermentation. Retrieved from https://www3.epa.gov/ttnchie1/efpac/ghg/ GHG_Biogenic_Report_draft_Dec1410.pd f.

Prinajati, P.D. (2020). Domestic Communal Wastewater Treatment Plant Evaluation in Sindangrasa, Bogor, Indonesia. Journal of Community Based Environmental Engineering and Management, 4(1), 31-36. Sleewijk, A.W., Oers, L.F.C.M., Guinee, J.B., Struijs, J., Huijbregts, A.J. (2008). Normalisation in product life cycle assessment: An LCA of the global and European economic systems in the year 2000. Science in The Total Environment, 390(1), 227-240.

Turovskiy, I. S. 2006. Wastewater Sludge Processing. U.S. : Library of Congress Cataloging -in Publication Data.

Yustiani, Y.M., Pradiko. H., Amrullah, R.H. (2018). The study of deoxygenation rate of Rangkui River water during dry season. International Journal of Geomate, 15(47), 164-169.

Zang, Q.H., Wang, X.C., Xiong, J.Q., Chen, R., Cao, B. (2010). Application of life cycle assessment for an evaluation of wastewater treatment and reuse project - Case study of Xi'an, China. Bioresources Technology, 101(5), 1421-1425.

http://www.gdrc.org/uem/lca/lca-define.html (accessed March 2017)

https://www.iges.or.jp/en/pub/wastewatermanagement-systems-indonesia/en (accessed March 2017) 